Syntax Literate : Jurnal Ilmiah Indonesia p-ISSN: 2541-0849

e-ISSN : 2548-1398

Vol. 6, No. 2, Februari 2021

\title{
KAMPANYE KESEHATAN COVID 19 DI MEDIA SOSIAL DALAM PERSPEKTIF INTERAKSIONISME SIMBOLIK
}

\author{
Atika Suri dan Irwansyah
}

Universitas Indonesia, Depok, Jawa Barat, Indonesia

Email: atika.suri@ui.ac.id dan irwansyah09@ui.ac.id

\section{Abstract}

The purpose of this study is to find out how Covid 19 health campaigns through social media in improving public sensitivity in complying with health protocols. The method in this study is the study of literature by delving into journals, books and news articles as well as data related to the theories used related to the Covid 19 Pandemic and by studying health camps in social media related to compliance with the Covid 19 protocol. The research approach uses qualitative by grouping selected journals and literature. The results obtained in this study are the invitation of figures and influencers on social media to influence public awareness in complying with health protocols. The presence of trauma in a person who loses a family or nearby krabat also affects the level of consciousness of the individual. In addition, the relationship between the campaign and social media users is also a factor in the success of health campaigns as conveyed through the song 'remember the mother's message' to be another alternative in improving public compliance with the health protocol covid 19. Symbolic Interaction Theory can still be the handle and basis of research to see how individuals capture symbols sent through health campaigns to then translate meaning and then obey and be implemented continuously. This theory is proven to remain relevant to measure various forms of communication in phenomena that continue to develop in society and its implementation in the development of the latest technology.

Keywords: symbolic interactionism; social media, covid 19; health campaign; covid 19 health protocol

\begin{abstract}
Abstrak
Tujuan dari penelitian ini yaitu untuk mengetahui bagaimana kampanye kesehatan Covid 19 melalui media sosial dalam meningkatkan kepekaan masyarakat dalam mematuhi protokol kesehatan. Metode dalam penelitian ini adalah studi literatur dengan cara mendalami jurnal-jurnal, buku-buku serta artikel pemberitaan termasuk juga data-data yang berkaitan dengan teori-teori yang digunakan terkait dengan Pandemi Covid 19 dan dengan mempelajari kampaye Kesehatan dalam sosial media terkait dengan kepatuhan terhadap protokol Covid 19. Pendekatanpenelitian menggunakan kualitatif dengan pengelompokkan jurnal dan literatur yang dipilih. Adapun hasil yang diperoleh dalam penelitian ini yaitu ajakan figure dan influencer di sosial media berpengaruh terhadap kesadaran masyarakat dalam mematuhi protocol kesehatan. Adanya trauma pada seseorang yang kehilangan keluarga atau krabat dekatnya juga mempengaruhi tingkat kesadaran
\end{abstract}


individu. Selain itu hubungan antara kampanye dan pengguna media sosial pun menjadi faktor suksesnya kampanye kesehatan seperti yang disampaikan melalui lagu 'ingat pesan ibu' menjadi alternatif lain dalam meningkatkan kepatuhan masyarakat terhadap protocol Kesehatan COVID-19. Teori Interaksionisme Simbolik tetap bisa menjadi pegangan dan dasar penelitian untuk melihat bagaimana individu menangkap simbol yang dikirimkan melalui kampanye kesehatan untuk kemudian menerjemahkan makna dan kemudian ditaati serta dilaksanakan secara berkesinambungan. Teori ini terbukti tetap relevan untuk mengukur berbagai bentuk komunikasi dalam fenomena-fenomena yang terus berkembang di masyarakat dan implementasinya dalam perkembangan teknologi terkini.

Kata kunci: interaksionisme simbolik; media sosial, covid 19; kampanye kesehatan; protokol kesehatan

Coresponden Author

Email: atika.suri@ui.ac.id

Artikel dengan akses terbuka dibawah lisensi

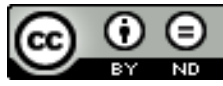

\section{Pendahuluan}

Teori Interaksionisme Simbolik termasuk teori psikologi sosial yang populer dan berpengaruh selama hampir satu abad terakhir. Ratusan buku, artikel dan penelitian membuktikan teori ini selalu menarik untuk diulas dan dipahami secara tuntas dalam berbagai bidang untuk meneliti fenomena sosial yang berkembang. Meskipun tidak secara spesifik, ide interaksionisme simbolik kerap muncul dalam tulisan-tulisan terkait Sosiologi, khususnya etnometodologi yakni ilmu tentang metode yang digunakan untuk meneliti bagaimana individu-individu menciptakan dan memahami kehidupan seharihari, dramaturgi, riset mengenai keluarga, teori peran identitas dan sosial, perilaku menyimpang dan fenomenologi (Praptiningsih, 2019). Interaksionisme Simbolik banyak juga dikaitkan dengan masalah sosial, studi budaya, feminis dan neo-marxism (Carter \& Fuller, 2016). Saat dicetuskan George Herbert Mead di tahun 1900-an, interaksionisme simbolik dianggap sebagai respon terhadap perspektif arus utama masyarakat yang mendominasi sosiologi pada saat itu. Pendekatan positivis yang dominan di masa itu cenderung memahami masyarakat dari atas ke bawah atau top down dan bersifat makro, serta bagaimana mereka memperlakukan dan membatasi individu (Carter \& Fuller, 2016). Sedangkan interaksionisme simbolik dikembangkan untuk memahami masyarakat dari bawah ke atas atau bottom up dan bersifat mikro. Inti dari pemikiran interaksionis simbolik adalah bahwa individu menggunakan bahasa dan simbol dalam komunikasi mereka dengan orang lain (Siregar, 2012). Interaksionisme simbolik menitikberatkan fokus analisisnya pada individu khususnya cara individu mempersepsikan dirinya dan lingkungannya (Abidin \& Djabbar, 2019).

Interaksi simbolik adalah aktivitas yang merupakan ciri dasar manusia, yakni komunikasi dan pertukaran simbol yang diberi makna (Indriani, 2016). Perilaku manusia harus dilihat sebagai proses yang memungkinkan manusia membentuk dan mengatur 
perilaku mereka dengan mempertimbangkan ekspektasi dari lawan bicara (Wirman \& Saputra, 2016). Karena mendalami bagaimana berkomunikasi, teori ini bisa digunakan dalam hampir semua fenomena yang berkembang termasuk untuk mengamati pertukaran simbol atau komunikasi di saat pandemi Covid 19 yang terjadi kini.

Tidak pernah ada yang menyangka bahwa di era modern saat ini dimana teknologi kedokteran dan pengobatan sudah sangat maju, penyebaran virus Covid 19 meluluhlantakan sendi ekonomi dan tatanan kehidupan berubah drastis akibat penularan virus Corona yang mulai menyebar di akhir tahun 2019. Tidak ada satupun negara, pemimpin, organisasi, komunitas hingga individu yang siap menghadapi penularan virus karena penyebarannya yang luar biasa oleh World Health Organisation (WHO) sudah dikategorikan sebagai pandemi kesehatan dunia. Corona virus disease 2019 atau disingkat Covid 19 merubah berbagai pola kehidupan masyarakat dalam sekejap. Cara manusia beraktivitas dan berkomunikasi kini harus diatur dalam protokol kesehatan yang menjadi turunan dari New Normal atau kenormalan baru yang ditetapkan pemerintah, salah satunya dengan memakai masker, mencuci tangan pakai sabaun dan lain-lain (Abdillah, 2020). Beruntung teknologi komunikasi sudah berkembang pesat. Di saat komunikasi tidak bisa lagi berlangsung secara tatap muka, maka teknologi komunikasi menjadi solusi. Apalagi saat ini sudah berkembang perangkat sosial media yang memungkinkan manusia berkomunikasi dua arah atau berkelompok saling mengirimkan simbol untuk dimaknai dan dibahas bersama.

Di era pandemi ini, sosial media menjadi pilihan untuk mengetahui perkembangan situasi termasuk mempelajari apa saja anjuran untuk terhindar dari penyebaran virus Covid 19 termasuk oleh pengguna di Indonesia (Adawiyah \& Kadir, 2020). Karena banyak digunakan selama pandemi, pihak berwenang di Indonesia juga menggunakan platform sosial media untuk gencar mengkampanyekan protokol kesehatan agar masyarakat terhindar dari penyebaran virus Covid 19. Sayangnya kampanye yang gencar di sosial media tidak berdampak pada penurunan jumlah orang positif Covid 19, jumlahnya bahkan terus bertambah.

Penelitian ini akan mengulas "Bagaimana kampanye kesehatan Covid 19 di Sosial Media dalam Perspektif Interaksionisme simbolik?” Adapun tujuan yang ingin dicapai dari penelitian ini yaitu untuk mengetahui bagaimana kampanye Kesehatan Covid 19 melalui media sosial dalam meningkatkan kepekaan masyarakat dalam mematuhi protokol kesehatan. Melalui konsep diri, individu akan menerjemahkan simbol-simbol yang ada, dalam hal ini kampanye Protokol Kesehatan untuk diterjemahkan dan menentukan langkah yang akan dilakukan individu dalam menerapkan protokol kesehatan. Penelitian ini diharapkan dapat memberikan gambaran bagaimana kampanye yang efektif untuk masyarakat agar secara sukarela mau menjalankan protokol kesehatan, yang akhirnya bisa menekan penyebaran virus dan menurunkan jumlah kasus positif Covid 19 di Indonesia. 


\section{Metode Penelitian}

Metode dalam penelitian ini adalah studi literatur dengan cara mendalami jurnaljurnal, buku-buku serta artikel pemberitaan termasuk juga data-data yang berkaitan dengan teori-teori yang digunakan terkait dengan Pandemi Covid 19. Penelitian juga dilakukan dengan mempelajari Kampanye Kesehatan khususnya kampanye Protokol Covid 19 di Sosial Media. Pendekatan dalam penelitian ini adalah kualitatif, dengan melakukan pengelompokkan jurnal atau literatur yang dipilih (Sugiyono, 2018).

Pertama peneliti mencoba melihat pemanfaatan Interaksionisme Simbolik dalam penelitian diberbagai bidang dalam 10 tahun terakhir. Kemudian mengelompokkan jurnal yang berkaitan dengan kampanye kesehatan Covid 19 di sosial media. Karena kasus Covid 19 baru saja terjadi, belum banyak literatur yang membahas Kampanye Protokol Covid 19 di media sosial dengan pendekatan teori Interaksionisme Simbolik. Untuk pengayaan, peneliti mencoba mendalami jurnal yang membahas kampanye protokol Covid 19 di media sosial dan mengkajinya dari sudut pandang Interaksionisme Simbolik.

Khusus untuk kampanye protokol Covid 19 di Indonesia, peneliti memilih sampel yang mewakili dengan pertimbangan: Pertama, materi kampanye dari sumber resmi pemerintah. Kedua, periode waktu yang dipilih adalah sejak pertengahan bulan September ketika PSBB tahap 2 kembali diperketat akibat melonjaknya angka positif Covid 19 di masyarakat. Ketiga, adalah materi kampanye yang tayang di aplikasi Instagram. Menurut Firma Kantar, aplikasi instagram sebagai salah satu aplikasi dengan pengguna terbesar selama Pandemi berlangsung.

\section{Hasil dan Pembahasan}

Di beberapa negara kampanye kesehatan Covid 19 melalui media sosial gencar dilakukan. Sebuah survey sekaligus kampanye kesehatan di Amerika Serikat dilakukan dengan menggunakan aplikasi sosial media facebook yang muncul dalam bentuk iklan. Pengguna facebook diajak untuk memahami kampanye kesehatan sekaligus mengikuti survey pemahaman terhadap kampanye terkait Covid 19. Hasilnya ternyata lebih banyak perempuan yang mau mengikuti dan menyelesaikan tahapan survey ini hingga akhir dibanding laki-laki. Tak hanya kampanye, aktifitas ini sekaligus menjadi strategi yang efektif dan efisien untuk mengumpulkan data berskala nasional tentang Covid 19 dalam waktu singkat. Data ini diharapkan bisa menjadi masukan evaluasi implementasi penanganan dan komunikasi bagi masyarakat terkait Covid 19 ataupun kasus krisis kesehatan lainnya (Ali et al., 2020). Survey ini membuktikan bahwa perempuan lebih peduli dan lebih ingin mematuhi protokol kesehatan dibanding laki-laki.

Namun dalam tinjauan interaksionisme simbolik kesadaran untuk menerapkan protokol kesehatan tidak bergantung pada jenis kelamin namun lebih pada pengalaman pribadi masing-masing individu. Dorongan ini yang membentuk kesadaran diri sendiri. Tanpa pengalaman, individu perlu waktu lama untuk bisa dipengaruhi oleh lingkungan termasuk kampanye lewat sosial media. Contohnya dalam kasus Covid 19 jika seseorang memiliki pengalaman yang traumatis terhadap teman atau keluarga yang 
positif Covid 19, maka pemahaman individu tersebut terhadap pentingnya menjalankan protokol Covid lebih baik dan dilakukan secara sukarela. Posisi berbeda menuntun pada pengamalan yang berbeda terhadap sebuah objek dalam hal ini kampanye kesehatan. Ada fenomena lain yang bergantung pada karakter mata yang melihat atau efek pengalaman masa lampau (Mead, 2018).

Keberhasilan kampanye kesehatan pada masyarakat sangat bergantung pada penggunaan platform yang tepat agar dapat melibatkan target sebanyak-banyaknya yang menjadi ukuran keberhasilan suatu kampanye. Sebuah kampanye kesehatan yang berawal di Inggris berhasil melibatkan banyak individu, tidak hanya di Inggris sendiri tetapi meluas ke berbagai negara di benua Eropa bahkan dilihat oleh banyak orang di luar Eropa. Kampanye ini adalah kampanye kesehatan yang dilakukan untuk menggugah kesadaran perempuan di Inggris untuk peduli dan mau mengikuti tes kanker serviks. Kanker serviks adalah kanker yang tumbuh pada rahim perempuan. Kanker ini adalah jenis kanker yang kedua terbanyak yang banyak dialami perempuan dibawah usia 45 tahun. Untuk deteksi dini perempuan dianjurkan untuk tes pap smear. Platform media sosial yang digunakan dalam kampanye ini adalah Twitter. Agar perempuan peduli dan sadar untuk melakukan dekteksi dini diluncurkan kampanye \#SmearForSmear yang diluncurkan lewat Twitter dan pada tahun 2015. Kampanye ini dilakukan dalam rangka Pekan Pencegahan Kanker Serviks Eropa. Cara mengikuti kampanye ini terbilang unik, setiap perempuan yang peduli dan bergabung dalam kampanye ini diharuskan melakukan swafoto atau foto selfie dengan menunjukkan bibir yang diolesi lipstik melewati garis bibir. Foto ini kemudian di upload di Twitter disertai pesan untuk mendorong peningkatan kesadaran sekaligus juga mempromosikan pentingnya deteksi dini kanker serviks. Hasilnya luar biasa, lebih dari 3000 unggahan swafoto yang dikirimkan dilihat oleh 500 juta orang. Selanjutnya dilakukan analisis konten untuk mengidentifikasi tweet yang menyampaikan pesan peningkatan kesadaran yang mempromosikan skrining kanker serviks. Studi ini menunjukkan bahwa keberhasilan kampanye kesehatan masyarakat menggunakan platform media sosial bergantung pada kemampuan insiatornya untuk melibatkan target. Namun dampak dari kampanye Twitter yakni meningkatkan kepedulian sejak dini terhadap kanker serviks masih harus dievaluasi.

Di Belanda kampanye dilakukan secara paralel di platform pemberitaan media online dan juga melalui peran influencer di sosial media terkait beberapa anjuran dalam menjalankan protokol Covid 19. Salah satu materi kampanye adalah mengajak masyarakat untuk disiplin mencuci tangan. Ada dua jenis materi kampanye yang disebarkan, yakni: tayangan video saja dan tayangan video beserta teks. Ternyata responden yang melihat video beserta teks yang lebih disiplin dalam mencuci tangan. Pengulangan pesan dalam kampanye kesehatan harus dilakukan untuk menunjukan apa yang disampaikan sangat penting. Gaya pesan menunjukan variasi linguistik dalam penyampaian pesan dengan perulangan, mudah mengerti dan perbendaharaan kata (Cahyono, 2018) (Liliweri, 2007). Dalam individu ada sebuah tindakan yang mirip dengan tindakan orang lain, dengan ini memungkinkan persyaratan terjadinya imitasi 
(Mead, 2018). Imitasi terjadi ketika ada stimulus untuk mengikuti atau melakukan reaksi dengan individu lain. Melalui media sosial, ini juga berlangsung dengan baik ketika dianjurkan untuk melakukan disiplin mencuci tangan dalam penelitian melalui influencer di Belanda. Artinya, meski melalui medium sosial media pesan dan anjuran terserap dengan baik dan bagi beberapa orang menjadi kebiasaan baru.

Penelitian online tentang hubungan kampanye protokol Covid 19 dengan tingkat penularan yang masih tinggi juga dilakukan di salah satu Provinsi di Pakistan, yakni Provinsi Punjab. Mayoritas responden $(58,1 \%)$ yang tinggal di daerah perkotaan memiliki pengetahuan yang lebih baik tentang virus Covid 19 dibandingkan dengan responden yang tinggal di pedesaan. Demikian pula perilaku higienis responden perkotaan lebih baik daripada responden pedesaan. Namun, tidak tersedianya masker, hand sanitizer serta alat pelindung diri lain dengan harga terjangkau, menjadi masalah utama masyarakat di negara ini sehingga tingkat penyebaran tidak kunjung berkurang. Kurang tersedianya sarana kesehatan warga untuk mengantisipasi penyebaran virus Covid 19 menjadi masalah di negara berkembang pada umumnya. Sementara beberapa fasilitas umum yang vital seperti transportasi umum membuat warga di negara berkembang tidak memiliki pilihan untuk menjaga jarak dan menghindari kerumunan. Kondisi ini memperbesar resiko penularan diantara individu. Sayangnya, keingian untuk tertib dan disiplin dalam menjalankan protokol kesehatan tidak bisa berjalan dengan baik ketika terbentur dengan keterbatasan ekonomi seperti yang dialami di Pakistan.

Dalam teori WHO perilaku kesehatan dipengaruhi pada, pertama, pemikiran dan perasaan, hasil pertimbangan individu terhadap objek atau stimulus merupakan modal awal untuk bertindak atau berperilaku, kedua, adanya acuan atau referensi dari seseorang atau pihak yang dipercaya, ketiga, sosio budaya yang mempengaruhi perilaku, dan keempat adalah sumber daya untuk mewujudkan keinginan (Mulyana, 2018). Pemahaman terhadap protokol kesehatan Covid 19 yang dalam interaksionisme simbolik adalah refleksi individu dari proses sosial atau pola tingkah laku yang terorganisir yakni kampanye sudah berhasil di Pakistan, namun pemahaman saja tidak cukup ketika masyarakat tidak mampu membeli atau mendapatkan perangkat kesehatan yang membuat mereka terlindung dari penyebaran virus.

Teori interaksionisme simbolik menjadi landasan dalam penelitian bagaimana masyarakat mau menaati protokol Kesehatan Covid 19 yang diterapkan. Aplikasi Telegram Crisis Preparedness and Response Center yang dikelola Kementerian Kesehatan Malaysia (KKM) diikuti oleh hampir 800 ribu individu. Interaksi di media sosial ini dikelompokkan terhadap tiga sasaran utama. Pertama, Interaksi media sosial antara KKM dengan pengguna media sosial. Kedua, interaksi media sosial antara KKM dengan Kerajaan. Ketiga, interaksi media sosial antara KKM dengan orang yang positif Covid 19. Melalui aplikasi ini disebarluaskan ajakan mematuhi protokol kesehatan setempat yang dikenal dengan Perintah Kawalan Pergerakan atau PKP, yang berlangsung mulai dari fase 1 hingga fase 3 . Pada fase 3 jumlah orang yang terpapar virus Covid 19 cenderung menurun. Kesadaran dan disiplin menjalankan protokol Covid 19 di kalangan masyarakat berperan besar menekan jumlah penderita. Hasil penelitian 
menyebutkan, Kampanye dengan pendekatan yang tepat kerjasama antara pemerintah dan Kerajaan berlangsung secara terus menerus membuat masyarakat secara sukarela menjalankan protokol Covid 19. Kesimpulannya teori interaksionisme simbolik berkaitan erat dengan gerakan sosial untuk menaati protokol kesehatan (Basir, Ab Rahim, \& Halim, 2020). Melibatkan kerajaan dalam penyebaran informasi kesehatan menjadi salah satu unsur yang menarik dalam kasus di Malaysia. Dalam tatanan masyarakat modern, tanpa disadari rasa terhubung dengan raja, seseorang bisa mendapatkan sebuah perasaan terhadap kelompok-kelompok masyarakat yang hadir bersama. Hubungan ini melibatkan penerimaan sebuah posisi yang lebih rendah, namun merupakan penerimaan yang dilakukan dengan senang hati karena maknanya secara luas yang dimungkinkan dalam tatanan ini (Mead, 2018).

Untuk Kampanye di Indonesia penelitian dilakukan terhadap akun Satgas Covid 19 Indonesia yang menggunakan medium Instagram dalam penyampaian kampanye. Akun ini resmi dikelola Satuan Tugas Penanganan Covid 19 Indonesia dan saat ini diikuti oleh 180 ribu pengguna. Akun ini muncul ketika pengguna Instagram membuka \#covid19 yang diakses oleh 17,3 juta jiwa di seluruh dunia. Sejak pertengahan September 2020 materi kampanye yang ditampilkan kebanyakan sama dengan materi kampanye sebelumnya yakni kampanye protokol kesehatan melalui infografis. Ada juga video dari beberapa tokoh negeri atau public figure yang ikut berpartisipasi menghimbau masyarakat untuk taat protokol Covid 19. Namun satu hal yang menarik sejak tanggal 1 Oktober Satgas Penanganan Covid 19 mengkampanyekan tema "Ingat Pesan Ibu" sebagai materi kampanye. Selain infografis, semboyan ini juga ditampilkan dalam bentuk video musik yang dibawakan oleh grup band beraliran rock alternative yakni grup band Padi. Dengan tema "ingat pesan ibu" diharapkan dalam beraktifitas masyarakat tetap melaksanakan 3M: mengenakan masker, mencuci tangan dan menjaga jarak dengan disiplin dan sungguh-sungguh. Sebagaimana kita senantiasa mengingat pesan ibu dalam segala hal, nasehat untuk mematuhi protokol kesehatan juga harus dituruti karena dengan kita mengingat nasehat ibu kita sendiri. Sosok ibu sengaja dihadirkan dalam pesan kampanye ini, agar kita melaksanakan protokol kesehatan sepenuh hati. Namun harus diteliti lebih lanjut, sejauhmana efektifitas kampanye dengan lagu ini. Apakah masyarakat hanya mengingat lagu atau juga sekaligus mengikuti anjuran dalam lagu ini. Pemilihan grup band Padi dan genre rock alternative mungkin tepat untuk kampanye di Instagram yang sebagian besar penggunanya adalah generasi muda. perlu digaris bawahi dalam teori interaksionisme simbolik dikenal istilah Imaji dalam hal ini mengimajinasikan sosok ibu. Lagu ingat pesan ibu diharapkan menjadi stimulus untuk menghadirkan sosok ibu. Imaji memiliki referensi representasional dalam hubungan sikap-sikap yang menjawab simbol-simbol ke dalam hubungan harmonis melalui penyusunan ulang konten-konten stimulus (Mead, 2018). Apakah hubungan individu dengan ibu terwakili oleh aliran musik Rock, atau musik yang lebih hangat, lembut dan intim sebagaimana umumnya hubungan anak dengan ibu. Pasti di akhir november atau hampir 2 bulan sejak kampanye \#IngatPesanIbu diluncurkan, jumlah angka positif Covid 19 cenderung meningkat. Data Satgas Penanganan Covid 19 
tercatat rekor baru di tanggal 29 November dengan penambahan angka postif 6.267 orang dalam satu hari. Satgas Penangan Covid 19 di akhir bulan Oktober sudah meluncurkan lagu baru, yang judulnya Iman, Aman, Imun. Himbauan dalam lagu tetap sama, tetapi ditampilkan oleh penyanyi yang berbeda. Perlu penelitian lebih mendalam berapa lama materi kampanye bisa ditayangkan, sebelum diganti dengan materi kampanye baru agar satu persatu pesan yang dibawakan bisa sampai dan diikuti anjurannya oleh masyarakat.

\section{Kesimpulan}

Dari pembahasan di atas dapat disimpulkan, ajakan figur yang dikagumi dan dipercayai masyarakat memiliki pengaruh dalam menyerap pesan kampanye kesehatan Covid 19 seperti yang dilakukan influencer di Belanda dan Keluarga Kerajaan di Malaysia. Faktor internal juga mempengaruhi ketaatan individu. Ketika mereka memiliki trauma karena ada keluarga dan kerabat yang menjadi korban Virus Covid, bahkan mungkin sampai meninggal dunia, maka pesan anjuran dalam kampanye akan lebih cepat lagi dijalankan secara disiplin oleh individu tersebut. Namun, pemahaman tinggi terhadap bahaya Covid tidak serta merta membuat individu disiplin menjalankan. Kasus di negara berkembang seperti Pakistan atau mungkin di Indonesia minimnya akses pada peralatan kesehatan yang memadai membuat masyarakat tetap rentan terhadap penularan virus Covid 19.

Hubungan antara media sosial yang dipilih dan isi kampanye juga erat kaitannya. Pengguna media sosial terbesar adalah generasi muda, sehingga materi kampanye harus dekat dengan pengguna mayoritas aplikasi tersebut. Sebagai contoh kampanye 'Ingat Pesan Ibu' yang dilakukan Satgas Penanganan Covid 19 perlu diteliti lebih lanjut untuk melihat efektifitas keberhasilan kampanye lagu yang dibawakan grup band rock yang anggotanya rata-rata berusia diatas 40 tahun.

Penelitian di Malaysia menjadi contoh lengkap ulasan sesuai landasan teori penelitian kali ini, yakni penggunaan pendekatan Interaksionisme Simbolik untuk Kampanye Kesehatan di Sosial Media. Sejak awal semua tahapan penelitian sudah melibatkan asumsi dasar Interaksionisme Simbolik. Sayangnya penelitian ini belum secara rinci menggambarkan mengapa pada akhirnya individu bisa berubah dan mau menaati protokol kesehatan yang digariskan pemerintah setempat sesuai kajian Interaksionisme Simbolik.

Interaksionisme simbolik selama hampir satu abad menjadi dasar dalam pendekatan berbagai fenomena yang terjadi di masyarakat. Di era sosial media ketika komunikasi mengalami banyak perubahan karena perkembangan teknologi, interaksionisme simbolik tetap dapat digunakan untuk mempelajari individu yang terlibat dalam komunikasi. Sampai kapanpun ketika komunikasi masih berlangsung, pemahaman dasar Interaksionisme simbolik tetap bisa menjadi alat ukur pertukaran simbol dan makna. Seperti klaim utama George Herbert Mead bahwa komunikasi atau talking to each other merupakan aktivitas paling manusiawi dan memanusiakan manusia. 


\section{BIBLIOGRAFI}

Abdillah, Leon. (2020). Stigma Terhadap Orang Positif COVID-19 (Stigma on Positive People COVID-19). Jambura Journal. Vol 2 No. 2

Abidin, Kurniati, \& Djabbar, Yusuf. (2019). Analisis Interaksi Simbolik Waria (Wanita Transgender) di Makassar-Indonesia Timur. Society, 7(2), 212-230.

Adawiyah, Dwi Putri Robiatul, \& Kadir, Nurhaya. (2020). Analisis Peran Media dalam Upaya Pencegahan Penyebaran Virus Corona (Covid-19) di Indonesia. Jurnal Mediakita: Jurnal Komunikasi Dan Penyiaran Islam, 4(1).

Ali, Shahmir H., Foreman, Joshua, Capasso, Ariadna, Jones, Abbey M., Tozan, Yesim, \& DiClemente, Ralph J. (2020). Social media as a recruitment platform for a nationwide online survey of COVID-19 knowledge, beliefs, and practices in the United States: methodology and feasibility analysis. BMC Medical Research Methodology, 20, 1-11.

Basir, Noriha, Ab Rahim, Ina Suryani, \& Halim, Mohamad Zaki Abdul. (2020). Analisis tingkah laku sosiologi masyarakat berasaskan teori interaksionisme melalui perangkaan data kes COVID-19 di Malaysia. Pendeta: Journal of Malay Language, Education and Literature, 11, 11-30.

Cahyono, Hery Bambang. (2018). Hambatan Komunikasi Antarbudaya Mahasiswa Thailand di Jember. Mediakom, 1(2).

Carter, Michael J., \& Fuller, Celene. (2016). Symbols, meaning, and action: The past, present, and future of symbolic interactionism. Current Sociology, 64(6), 931-961.

Indriani, Ririn. (2016). Makna Interaksi Simbolik Dalam Proses Upacara Pernikahan Suku Buton Lapandewa Kaindea di Samarinda. E-Journal Ilmu Komunikasi, 4(3), 265-279.

Liliweri, A. (2007). Dasar-dasar Komunkasi Kesehatan. Yogyakarta: Pustaka Belajar.

Mead, George Herbert. (2018). Mind, Self, and Society (Pikiran, Diri dan Masyarakat). William Saputra, Penerjemah). Yogyakarta: Forum Grup Relasi Inti Media.

Mulyana, D. et al. (2018). Komunikasi Kesehatan Pemikiran \& Penelitian. Bandung: Remaja Rosdakarya.

Praptiningsih, Novi Andayani. (2019). Implementation of Business Communication in Gay Dramaturgy. Perspektif Komunikasi: Jurnal Ilmu Komunikasi Politik Dan Komunikasi Bisnis, 2(2).

Siregar, Nina Siti Salmaniah. (2012). Kajian Tentang Interaksionisme Simbolik. Perspektif, 1(2), 100-110. 
Kampanye Kesehatan Covid 19 di Media Sosial dalam Perspektif Teori Interaksionisme Simbolik

Sugiyono. (2018). Metode penelitian pendidikan pendekatan kuantitatif, kualitatif, dan $R \& D$. Bandung: Alfabeta.

Wirman, Welly, \& Saputra, Muhammad Nanda. (2016). Fenomena Komunikasi Mahasiswi Lesbian Label Butch di Kota Pekanbaru. Skripsi. Riau University. 